\title{
UJI MORTALITAS KUMBANG BERAS (Sitophilus oryzae) DENGAN PENGENDALIAN HAYATI JAMUR Beauveria bassiana
}

\author{
Intan Junita Artia $^{1 *}$, Dian Mutiara $^{2}$, Dewi Novianti $^{3}$ \\ ${ }^{1,2,3}$ Program Studi Biologi, Fakultas Sains dan Teknologi \\ Universitas PGRI Palembang \\ *e-mail: ntnartia@gmail.com
}

\begin{abstract}
Research on mortality test of rice beetle (Sitophilus oryzae) with the biological control of the fungus Beauveria basianna. The purpose of the research was to analyze the mortality ability of S. oryzae against B.basianna which was carried out from March to April 2021 at the Microbiology and Biotechnology Laboratory, Faculty of Science and Technology PGRI Palembang university. The study used RAL, namely the administration of B.basianna with different concentrations consisting of 5 treatments and 4 replications, namely P0 (as control), P1 $\left(10^{3}\right.$ konidia cfu/ml $)$, P2 $\left(10^{4}\right.$ konidia cfu/ml $)$, P3 $\left(10^{5}\right.$ konidia cfu $\left./ \mathrm{ml}\right)$, P4 $\left(10^{6}\right.$ konidia $\mathrm{cfu} / \mathrm{ml})$, P5 $\left(10^{7}\right.$ konidia $\left.\mathrm{cfu} / \mathrm{ml}\right)$. The results showed that there was an effect of treatment concentration on S.oryzae mortality. Treatment P5 $\left(10^{7}\right.$ konidia cfu/ml $)$ resulted in the highest mortality percentage with an average of $28.75 \%$.
\end{abstract}

Keywords: Beauveria bassiana, Sitophilus oryzae, mortality.

\begin{abstract}
ABSTRAK
Penelitian uji mortalitas kumbang beras (Sitophilus oryzae) dengan pengendalian hayati jamur Beauveria basianna. Tujuan penelitian untuk menganalisis kemampuan mortalitas $S$. oryzae terhadap B. basianna yang dilakukan pada bulan Maret hingga Mei 2021 di Laboratorium Mikrobiologi dan Bioteknologi Fakultas Sains dan Teknologi universitas PGRI Palembang. Penelitian menggunakan RAL yaitu pemberian $B$. basianna dengan konsentrasi yang berbeda-beda yang terdiri dari 5 perlakuan dan 4 ulangan yaitu $\mathrm{P}_{0}$ (kontrol), $\mathrm{P}_{1}\left(10^{3}\right.$ konidia cfu/ml $), \mathrm{P}_{2}\left(10^{4}\right.$ konidia cfu/ml $), \mathrm{P}_{3}\left(10^{5}\right.$ konidia cfu $\left./ \mathrm{ml}\right), \mathrm{P}_{4}\left(10^{6}\right.$ konidia $\mathrm{cfu} / \mathrm{ml}), \quad \mathrm{P}_{5}\left(10^{7}\right.$ konidia $\left.\mathrm{cfu} / \mathrm{ml}\right)$. Hasil penelitian menunjukkan adanya pengaruh konsentrasi perlakuan terhadap mortalitas S.oryzae. Perlakuan $\mathrm{P}_{5}\left(10^{7}\right.$ konidia cfu/ml $)$ menghasilkan persentase mortalitas tertinggi dengan rata-rata sebesar $28,75 \%$.
\end{abstract}

Kata Kunci: Beauveria bassiana, Sitophilus oryzae, mortalitas.

\section{PENDAHULUAN}

Beras merupakan makanan pokok masyarakat Indonesia. Seiring dengan pertambahan jumlah penduduk yang mengakibatkan permintaan pasokan beras di Indonesia semakin meningkat setiap tahun (Hardison dan Angga, 2020). Menurut BPS (2019), kebutuhan konsumsi beras di tahun 2020 sebesar 31,63 juta ton, mengalami kenaikan sebanyak 314,10 ribu ton dibandingkan pada tahun 2019 sebesar 31,31 juta ton. 
Proses penyimpanan beras pada gudang salah satu langkah terpenting setelah panen. Dalam penyimpanan beras tidak terlepas dari masalah organisme pengganggu terutama dari golongan serangga (Manueke dan Pelealu, 2015). Kumbang beras (Sitophilus oryzae) merupakan serangan hama yang dapat merusak beras serta menurunkan kualitasnya selama penyimpanan beras pada gudang. Kerusakan tersebut berupa kerusakan fisik, kimiawi dan mikrobiologis yang mengakibatkan penurunan kualitas hasil pertanian (Febrianti dan Suharto, 2019). Kerugian dari segi ekologi yang diakibatkan dari serangga hama kumbang beras yaitu dapat menyebabkan terjadinya ledakan populasi serangga yang tidak dapat terkontrol (Rizal et al., 2019).

Pengendalian kumbang beras masih banyak menggunakan insektisida sintetik yang dilakukan secara intensif yang mengakibatkan berbagai dampak negatif, terutama terbunuhnya musuh alami dan akumulasi residu pestisida (Hasnah et al., 2012). Sakul et al., (2012) pengendalian kumbang beras sampai saat ini masih menggunakan pestisida dan fumigasi yang digunakan dalam gudang - gudang Bulog yakni Phosphine dan

\section{BAHAN DAN METODE}

Penelitian ini telah dilaksanakan pada bulan Maret sampai Mei 2021 di Laboratorium Mikrobiologi dan Bioteknologi Fakultas Sains dan Teknologi Universitas PGRI Palembang. Alat dan bahan yang digunakan yaitu: autoklaf, kantong plastik hitam, tabung reaksi, gelas ukur, erlenmeyer, beker glass, cawan petri, timbangan, toples, sprayer, spatula, masker, pipet tetes, alat tulis, kamera handphone, isolat Beauveria bassiana, kumbang beras (Sitophilus oryzae), aquadest, alkohol $70 \%$, detergen, Laminar air flaw, tissue
Metyl bromide. Rizal et al, (2010) penggunaan secara alami juga dapat digunakan dalam melakukan pengendalian kumbang beras. Sopialena (2018), pengendalian hayati aman bagi lingkungan karena tidak merugikan organisme non target dan tidak menyebabkan ledakan hama kedua maupun resurgensi hama. Salah satu cara alternatif yang cukup potensial dengan menggunakan jamur entomopatogen yaitu Beauveria bassiana. Mandasari et al., (2015) Beauveria bassiana salah satu jenis jamur entomopatogen yang digunakan sebagai agen pengendali hayati berbagai hama. Banyak serangga hama dapat dikendalikan oleh $B$. bassiana secara efektif.

$$
\text { Berdasarkan uraian latar }
$$
belakang diatas menunjukkan bahwa kumbang beras adalah serangga hama yang dapat merusak dan menurunkan kualitas beras. Salah satu alternatif yang dapat dilakukan untuk mencegah kumbang beras dengan menggunakkan agen hayati jamur B.bassiana, sehingga perlu dilakukan penelitian lebih lanjut mengenai Uji Mortalitas Kumbang Beras (S.oryzae) dengan Pengendalian Hayati Jamur B. bassiana.

dan beras. Penelitian ini merupakan percobaan eksperimen untuk menganalisis hasil uji mortalitas kumbang beras ( $S$. oryzae) dengan pengendalian hayati $B$. bassiana menggunakan Rancangan Acak Lengkap (RAL) dengan menggunakan 6 perlakuan dan 4 ulangan.

\section{Proses Perbanyakan Kumbang Beras (Sitophilus. oryzae)}

Kumbang beras sebanyak 30 ekor jantan, 30 ekor betina yang telah teridentifikasi direaring. Toples berukuran $10 \mathrm{~L}$ diisi beras sebanyak 4 kg. Kumbang beras yang telah disiapkan dimasukkan ke dalam toples dan ditutup 
dengan plastik hitam, diamkan selama 23 bulan hingga mendapatkan keturunan ketiga (F3).

\section{Sterilisasi Alat}

Peralatan yang digunakan seperti tabung reaksi, erlenmeyer, beker glass, pipet tetes dan cawan petri dicuci menggunakan detergen, dibilas lalu keringkan, kemudian disterilkan dalam autoklaf pada suhu $121^{\circ} \mathrm{C}$ dengan tekanan 15 lbs selama 15 menit.

\section{Uji Mortalitas dengan Pengaplikasian Jamur $B$. bassiana Terhadap Kumbang Beras ( $S$. oryzae)}

Toples plastik disiapkan sebanyak 24 buah. Masing-masing toples diisi sebanyak 100 gram beras dan 20 ekor kumbang beras. Pengaplikasian suspensi B.bassiana dilakukan dengan cara menyemprotkan suspensi konidia pada kumbang beras satu kali sebanyak satu $\mathrm{ml}$. Toples dibungkus menggunakan plastik hitam dan diletakkan di atas meja sesuai dengan tata letak unit perlakuan.
Pengamatan mortalitas dilakukan setiap hari selama 10 hari.

\section{Analisis Data}

Jumlah kematian kumbang beras $(S$. oryzae) dihitung pada hari ke-10 dengan menggunakan rumus berikut:

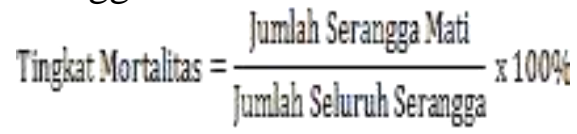

(Sumber: Raya et al., 2014)

Data yang telah diperoleh dianalisis dengan Analisis Sidik Ragam (Ansira). Bila berpengaruh nyata, maka dilanjutkan dengan uji beda nyata terkecil (BNT)

\section{HASIL DAN PEMBAHASAN}

Hasil penelitian selama 10 hari tentang uji mortalitas kumbang beras (Sitophilus oryzae) dengan pengendalian hayati jamur Beauveria bassiana didapatkan data seperti pada Tabel 1 dibawah ini :

Tabel 1. Rerata mortalitas $S$. oryzae sampai hari ke-10 pada beberapa konsentrasi B. Bassiana

\begin{tabular}{|c|c|}
\hline $\begin{array}{c}\text { Perlakuan } \\
\text { Konsentrasi B.bassiana }\end{array}$ & $\begin{array}{l}\text { Rata-rata Mortalitas } \\
\text { S.oryzae }(\%)\end{array}$ \\
\hline P0(Kontrol) & 0 \\
\hline P1 $\left(10^{3}\right.$ konidia $\left.\mathrm{cfu} / \mathrm{ml}\right)$ & 1,25 \\
\hline $\mathrm{P} 2\left(10^{4}\right.$ konidia $\left.\mathrm{cfu} / \mathrm{ml}\right)$ & 2,5 \\
\hline $\mathrm{P} 3\left(10^{5}\right.$ konidia $\left.\mathrm{cfu} / \mathrm{ml}\right)$ & 5 \\
\hline $\mathrm{P} 4\left(10^{6}\right.$ konidia $\left.\mathrm{cfu} / \mathrm{ml}\right)$ & 13,75 \\
\hline $\mathrm{P} 5\left(10^{7}\right.$ konidia $\left.\mathrm{cfu} / \mathrm{ml}\right)$ & 28,75 \\
\hline
\end{tabular}

Dari hasil penelitian pada Tabel 1 Hasil mortalitas S.oryzae dengan pemberian $B$. bassiana dilakukan Uji
Analisis Sidik Ragam. Hasil ANSIRA dapat dilihat pada Tabel 2. 
Mortalitas Kumbang Beras (Sitophylus oryzae)..., Intan Junita Artia, Dian Mutiara, Dewi Novianti, Indobiosains Volume 4 No. 1, Februari 2022, 9-14.

Tabel 2. Analisis Sidik Ragam Pemberian B.bassiana Terhadap Mortalitas S.oryzae pada hari Ke-10

\begin{tabular}{llllll}
\hline $\begin{array}{c}\text { Sumber } \\
\text { Ragam }\end{array}$ & DB & JK & KT & F hitung & $\begin{array}{l}\mathbf{F}_{\text {tabel }} \\
\mathbf{5 \%}\end{array}$ \\
\hline Perlakuan & 5 & 64,16 & 12,83 & 31,51 & 2,77 \\
Galat & 18 & 44,8 & 2,48 & & \\
Total & 23 & 108,96 & & & \\
\hline
\end{tabular}

Keterangan $: *=$ Berpengaruh nyata

Berdasarkan hasil Analisis Sidik Ragam (ANSIRA) pada Tabel 2 mortalitas S.oryzae dengan pemberian B.bassiana didapatkan hasil bahwa $\mathrm{F}_{\text {hitung }}$ $31,51>\mathrm{F}_{\text {tabel }} 2,77$, artinya perlakuan pemberian B.bassiana memberikan pengaruh nyata terhadap mortalitas S.oryzae. $\mathrm{F}_{\text {hitung }}>\mathrm{F}_{\text {tabel }}$ maka dilanjutkan dengan uji Beda Nyata Terkecil (BNT). Hasil uji BNT dapat dilihat seperti pada Tabel 3 dibawah ini :

Tabel 3. Hasil Uji Beda Nyata Terkecil (BNT) mortalitas S.oryzae dengan pemberian B.bassiana.

\begin{tabular}{|c|c|c|}
\hline $\begin{array}{c}\text { Perlakuan } \\
\text { Konsentrasi B.bassiana }\end{array}$ & \multicolumn{2}{|c|}{ Rata-rata Mortalitas S.oryzae (\%) } \\
\hline P0 (Kontrol) & 0 & $\mathrm{a}$ \\
\hline P1 $\left(10^{3}\right.$ konidia $\left.\mathrm{cfu} / \mathrm{ml}\right)$ & 1,25 & $\mathrm{~b}$ \\
\hline P2 $\left(10^{4}\right.$ konidia $\left.\mathrm{cfu} / \mathrm{ml}\right)$ & 2,5 & $\mathrm{c}$ \\
\hline P3 $\left(10^{5}\right.$ konidia $\left.\mathrm{cfu} / \mathrm{ml}\right)$ & & $\mathrm{d}$ \\
\hline P4 $\left(10^{6}\right.$ konidia $\left.\mathrm{cfu} / \mathrm{ml}\right)$ & 13,75 & $\mathrm{e}$ \\
\hline P5 $\left(10^{7}\right.$ konidia cfu $\left./ \mathrm{ml}\right)$ & 28,75 & $\mathrm{f}$ \\
\hline $\mathrm{BNT}_{0,05}=1,15$ & & \\
\hline
\end{tabular}

Keterangan: Rata-rata dalam tabel yang diikuti oleh huruf yang sama artinya berbeda tidak nyata berdasarkan uji BNT 5\%.

Berdasarkan Tabel 3 dapat dilihat bahwa hasil uji BNT pemberian B.bassiana terhadap mortalitas S.oryzae memiliki nilai berbeda nyata dan berbeda tidak nyata pada masing-masing perlakuan. Hal tersebut dilihat dari nilai notasi pada setiap perlakuan. Pada perlakuan $\mathrm{P}_{0}$ (kontrol) berbeda nyata dengan $\mathrm{P}_{1}, \mathrm{P}_{2}, \mathrm{P}_{3}, \mathrm{P}_{4}$ dan $\mathrm{P}_{5}$. Pada perlakuan $\mathrm{P}_{1}, \mathrm{P}_{2}, \mathrm{P}_{3}, \mathrm{P}_{4}$ dan $\mathrm{P}_{5}$ berbeda tidak nyata dengan $\mathrm{P}_{0}$. Hal ini menunjukkan bahwa perlakuan B.bassiana terhadap mortalitas S.oryzae berbeda nyata pada perlakuan $\mathrm{P}_{1}, \mathrm{P}_{2}, \mathrm{P}_{3}$, $\mathrm{P}_{4}$ dan $\mathrm{P}_{5}$ tetapi berbeda tidak nyata dengan $\mathrm{P}_{0}$. Perlakuan yang tertinggi pada perlakuan $\mathrm{P}_{5}$ dengan konsentrasi $10^{7}$ konidia cfu/ml dengan rata-rata persentase mortalitas S.oryzae yang yaitu $28,75 \%$.

Pada perlakuan $\mathrm{P}_{0}$ (kontrol) tidak menunjukkan adanya mortalitas S.oryzae sehingga rata-rata persentase mortalitas $0 \%$. Pada perlakuan $\mathrm{P}_{1}\left(10^{3}\right.$ konidia $\mathrm{cfu} / \mathrm{ml})$ menunjukkan adanya mortalitas sebanyak 1 ekor S.oryzae dengan ratarata persentase mortalitas $1,25 \%$. Pada perlakuan $\mathrm{P}_{2} \quad\left(10^{4}\right.$ konidia $\left.\mathrm{cfu} / \mathrm{ml}\right)$ menunjukkan adanya mortalitas sebanyak 2 ekor S.oryzae dengan rata-rata persentase mortalitas 2,5\%. Pada perlakuan $\mathrm{P}_{3} \quad\left(10^{5}\right.$ konidia $\left.\mathrm{cfu} / \mathrm{ml}\right)$ menunjukkan adanya mortalitas sebanyak 4 ekor S.oryzae dengan rata-rata 
persentase mortalitas $5 \%$. Pada perlakuan $\mathrm{P}_{4}\left(10^{6}\right.$ konidia cfu/ml $)$ adanya mortalitas sebanyak 11 ekor S.oryzae dengan ratarata persentase mortalitas $13,75 \%$ dan pada perlakuan $\mathrm{P}_{5}\left(10^{7}\right.$ konidia $\left.\mathrm{cfu} / \mathrm{ml}\right)$ adanya mortalitas sebanyak 23 ekor S.oryzae dengan rata-rata persentase mortalitas 28,75\%. Perlakuan $\mathrm{P}_{5}$ menunjukkan nilai rata-rata tertinggi sedangkan $\mathrm{P}_{0}$ menunjukkan nilai rata-rata terendah pada mortalitas S.oryzae.

$\begin{array}{lll}\text { Perlakuan } & \mathrm{P}_{0} \quad \text { (kontrol) }\end{array}$ menunjukkan rata-rata persentase mortalitas S.oryzae terendah dengan tingkat mortalitas $\%$, diduga karena $\mathrm{P}_{0}$ sebagai kontrol atau tanpa pemberian konsentrasi konidia B.bassiana sehingga tidak ada S.oryzae yang terinfeksi sedangkan pada perlakuan $\mathrm{P}_{1}, \mathrm{P}_{2}, \mathrm{P}_{3}, \mathrm{P}_{4}$ dan $\mathrm{P}_{5}\left(10^{7}\right.$ konidia $\left.\mathrm{cfu} / \mathrm{ml}\right)$ diduga konsentrasi konidia B.bassiana dapat menginfeksi S.oryzae sehingga menghasilkan mortalitas. Menurut Yassin et al., (2020) semakin tinggi perbandingan tingkat kerapatan konsentrasi konidia B.bassiana yang digunakan dapat menyebabkan semakin tinggi tingkat mortalitas S.oryzae. Pada pengamatan hari pertama sampai hari kedua setelah aplikasi B.bassiana yang dilakukan secara kontak langsung dengan disemprotkan pada tubuh serangga belum menyebabkan adanya kematian S.oryzae pada semua perlakuan. Hal ini disebabkan karena.bassiana

\section{KESIMPULAN}

Berdasarkan hasil penelitian dapat disimpulkan bahwa Semakin tinggi kerapatan konidia maka semakin tinggi pula tingkat mortalitas serangga S.oryzae. B.bassiana memiliki pengaruh nyata dalam mengendalikan S.oryzae. Perlakuan yang tertinggi terjadi pada perlakuan $\mathrm{P}_{5}$. Perlakuan dengan konsentrasi $10^{7}$ konidia cfu/ml yang memiliki rata-rata mortalitas S.oryzae yaitu $28,75 \%$. membutuhkan waktu untuk dapat menginfeksi dan mematikan serangga uji, karena konidia jamur yang menempel pada kutikula akan terlebih dahulu berkecambah membentuk hifa sehingga baru dapat menembus kutikula. Hal ini didukung oleh Ardiyati et al., (2015) bahwa metode kontak langsung dengan cara konidia disemprotkan pada tubuh serangga bertujuan agar konidia jamur hanya menempel pada kutikula inang. Menurut Hasnah et al., (2012) B.bassiana memerlukan waktu untuk dapat menembus integumen hingga menimbulkan infeksi dan kematian. Penetrasi berlangsung dalam waktu 12-24 jam dan hal tersebut memiliki proses untuk masuk kedalam tubuh dengan keadaan lingkungan yang mendukung (Simanjuntak, 2017). Pengaruh perlakuan konsentrasi B.bassiana pada setiap perlakuan mengalami mortalitas setelah pengamatan hari ke-3. Perbedaan persentase mortalitas pada S.oryzae yang terinfeksi B.bassiana terjadi karena perbedaan konsentrasi konidia B.bassiana yang diaplikasikan pada masing-masing perlakuan. S.oryzae yang terinfeksi lebih banyak terjadi pada perlakuan konsentrasi yang memiliki suspensi tinggi, yang dapat mengakibatkan persentase kematian S.oryzae yang tinggi pula.

\section{DAFTAR PUSTAKA}

Ardiyati, A. T., G. Mudjiono., dan T. Himawan. 2015. Uji Patogenisitas Jamur Entomopatogen Beauveria bassiana (Balsamo) Vuillemin pada Jangkrik (Gryllus sp.) (Orthoptera: Gryllidae). Jurnal HPT. 3(3): 4351.

Badan Pusat Statistik. 2019. Statistik Luas Panen dan Produksi Padi Indonesia. BPS RI, Jakarta. 
Febrianti, S. Z., dan Suharto. 2019. Pengaruh Fosfin (PH3) Terhadap Mortalitas Hama Gudang Sitophilus oryzae Pada Komoditas Gandum. Jurnal Bioindustri. 2(1): 274-284.

Hardison., dan A. Pramana. 2020. Analisis Perubahan Kebijakan Ketahanan Pangan Beras di Provinsi Riau. Jurnal Administrasi Politik dan Sosial. 1(2): 76-83.

Hasnah., Susanna., dan H. Sably. 2012. Keefektifan Jamur Jamur Beauveria bassiana Vuill Terhadap Mortalitas Kepik Hijau Nezara viridula L. Pada Stadia Nimfa Dan Imago. Jurnal Floratek. 7: 13 - 24.

Mandasari, L. F., R. Hasibuan., A. M. Hariri., dan Purnomo. 2015. Pengaruh Frekuensi Aplikasi Isolat Jamur Entomopatogen Jamur Beauveria bassiana Terhadap Kutu daun (Aphis glycines Matsumura) dan Organisme Non-Target Pada Pertanaman Kedelai. Jurnal Agrotek Tropika. 3(3): 384-392.

Manueke, J., dan J. Pelealu. 2015. Ketertarikan Hama Sitophilus oryzae Pada Beras, Jagung Pipilan Kacang Tanah, Kacang Kedelai, Dan Kopra. Jurnal Eugenia. 21(2): 70-79.

Raya, Y. A. A., I Gede, S., dan Indriyati. 2014. Uji Patogenisitas Jamur Beauveria bassiana Yang Diisolasi Dari Hypothenemus hampeipada Sitophilus oryzae di Tingkat Laboratorium. Jurnal Agrotek Tropika. 2(1): 115 118, Januari.
Rizal, S., D. Mutiara., dan D. Agustina. 2019. Preferensi Konsumsi Kumbang Beras (Sitophilus oryzae) Pada Beberapa Varietas Beras. Jurnal Ilmiah Matematika dan Ilmu Pengetahuan Alam. 16(2): 157165.

Rizal, S., D. Mutiara., dan I. Lestari. 2010. Uji Toksisitas Akut Serbuk Kering Daun Sirsak (Annona muricata Linn.) Terhadap Kutu Beras (Sitophilus oryzae)

Sakul, E. H., J. S. S. Manoppo., D. Taroreh., R. I. F. Gerungan., dan S. Gugule. 2012. Pengendalian Hama Kumbang Logong (Sitophylus oryzae L.) Dengan Menggunakan Ekstrak Biji Pangi (Pangium edule Reinw.). Jurnal Eugenia. 18(3): 186-197.

Simanjuntak, N. R. 2017. Patogenisitas Beauveria bassiana (Bals.) Terhadap Larva Chilo sacchariphagus Boj. (Lepidoptera: Crambidae) Di Laboratorium. Skripsi Program Studi Agroteknologi Fakultas Pertanian Universitas Sumatera Utara (Tidak dipublikasi).

Sopialena. 2018. Pengendalian Hayati Dengan Memberdayakan Potensi Mikroba. Mulawarman University Press. Samarinda.

Yassin, M. A., N. Rochman., dan Setyono. 2020. Kemangkusan Metarhizium anisoplae dan Jamur Beauveria bassiana Sebagai Bioinsektisida Bagi Hama Gudang Sitophilus oryzae. JurnalAgronida.6(1):14- 21. 